\title{
TRATAMENTO DA PARALISIA FACIAL DE BELL PELA CORTISONA
}

\section{A. AKERMAN *}

Encontradiça na clínica, a paralisia de Bell apresenta etiologia muito discutida. Pesquisas dos últimos anos, em particular verificações cirúrgicas, na fase inicial, parecem estabelecer que o mecanismo mais plausível de sua produção seria um edema inflamatório agudo do nervo ou das partes que o constituem, assim como de seus envoltórios. A reação congestiva ou inflamatória inespecífica (fenômenos vasomotores, exsudação), por si só, ou a consequiente isquemia do nervo e sua bainha, no canal ósseo, bloqueariam o fluxo nervoso. Os mais diversos fatôres poderão desencadear essas reações: infeç̧ões mínimas das vias respiratórias superiores, infeç̧ões otológicas subclínicas, exposição ao frio, vento, etc. Há, incontestàvelmente, predisposições individuais, anatômicas e reacionais. Embora grande parte das paralisias de Bell cure espontâneamente, ao fim de algumas semanas, certo número persiste, criando sérios problemas clínicos. Sabe-se que a duração da fase aguda, antes de se iniciarem as melhoras, influi decisivamente na frequiência das sequielas, em consequiência da degeneração do nervo.

$O$ emprêgo da cortisona, na paralisia de Bell, foi sugerido por Rothendler, em 1951, baseado nas propriedades dêsse esteróide de inibir o edema e os processos inflamatórios em geral.

'Tratamos, pela cortisona, nos primeiros dias da instalação da paralisia facial periférica, 10 pacientes, dos quais 2 crianças. A recuperação completa das funções fêz-se em 9 casos em menos de duas semanas, e no décimo caso, no fim da terceira semana.

Parece-nos, diante dessas observações, que a cortisona é um agente terapêutico eficaz quando utilizado a tempo, isto é, logo no início da instalaçâo da paralisia facial. Entretanto, para chegar-se a conclusões mais definitivas, é óbvio ser necessária casuistica mais numerosa, pois trata-se de processo patológico que, muitas vêzes, evolui espontâneamente para a cura. 